searches in response to specific demands. The collection of material on which the searches were made consisted of more than half a million citations to journal articles in the biomedical field, input to the January 1964 and subsequent issues of the monthly Index Medicus. This collection is growing at the approximate rate of 200,000 citations per year. Articles from about 2,400 scientific journals are indexed at an average level of $6 \cdot 7$ terms per item using a controlled vocabulary of Medical Subject Headings (MeSH). Over three thousand demand searches are processed annually at the National Library of Medicine, additional searches being handled at regional MEDLARS centres in the United States, in the United Kingdom and in Sweden. 'The present study was confined to the United States. A demand search is conducted by a serial search of the index term profiles of the 700,000 citations on magnetic tape. This search is essentially a matching process; the index term profiles of journal articles are matched against a search formulation, which is a translation of a subject request into the controlled vocabulary of the system.

The principal objectives of the test programme included a study of the demand search requirements of the users: the determination of how effective and efficient the present service is in meeting these requirements: and how the requirements of users could be met in the future.

The results showed that on average the system retrieves about 65 per cent of the "major value" literature from its collection of data. Few of the individual search results, however, were in the area bounded by the average ratios \pm 5 per cent. In fact, the results were widely scattered. Some of the searches appear to have performed well with high recall accompanied by high precision. Other searches had very unsatisfactory recall results. It seems that a rather different average result was expected. The report states that the system was expected to function in a high recall, low precision way, in the region of, for example, $75-90$ per cent recall at $10-20$ per cent precision. It is suggested that the reason why on average MEDLARS is operating at 58 per cent recall and 50 per cent precision may be because the searchers, unconsciously or consciously, choose to operate in this general area. MEDLARS is now retrieving an average of 175 citations per search; to operate at an average recall of 85-90 per cent, and an average ratio around 20-25 per cent, would mean that MEDLARS would need to retrieve in each search an average of 500-600 citations. which many users would not be willing to scan. Little is in fact known about the recall and precision requirements and tolerances of MEDLARS users. The report suggests, however, that a decision on this subject ought not to be fixed. Each user has his requirements and the MEDLARS demand search request form ought to be redesigned to cater for recall requirements and precision tolerances of each user.

\section{How Did Mycenae Fall?}

A sURVEY of available palaeoclimatological evidence by $\operatorname{Dr} H$. E. Wright, director of the Limnological Research Center of the University of Minnesota, seems to cast doubt on the suggestion that the fall of Mycenae was brought about by a climatic change. This idea was put forward by Professor Rhys Carpenter in a book called Discontinuity in Greek Civilization (Cambridge, 1966 ) in which he suggested that the extension of the summer droughts into autumn and spring caused repeated failure of crops in southern Greece and thus the breakdown of the Mycenaean economy. Professor Rhys Carpenter suggested that this resulted in the abrupt fall of the civilization-in about $1200-1000 \mathrm{BC}$ -an event which has never been adequately explained.

In the current issue of Antiquity (XLII, 123: 1968) Dr Wright reviews the evidence for this hypothesis which is available from pollen remains found in layers of soil dating from the time of the fall of Mycenae. He has found no indication of any vegetational change? that could have accompanied a climatic change in the Mediterranean region during Mycenaean times. Analysis of pollen from soil layers on the southern Dalmatian coast, 250 miles north of Greece, has shown that the Mediterranean evergreen oak has dominated the landscape since $4300 \mathrm{BC}$ with no sign of a climatic change. In north-western Turkey, although a reduction in the forests of beech and fir at about $2000 \mathrm{BC}$ may reflect a change to a drier climate at that time, there was no significant change around $1200 \mathrm{BC}$.

In Peloponnesus, pollen from the Osmanaga lagoon near Pylos has shown that there was an increase in the growth of olive trees to about 40 per cent of the total vegetation at about $1000-600 \mathrm{BC}$. These must have been cultivated, for wild olives now form a very small part of the Mediterranean vegetation. This seems to indicate that olive-growing characterized the postMycenaean period--known as the Greek dark ages-from 1100 to $800 \mathrm{BC}$. Dr Wright suggests that at that time olives were the chief subsistence crop, whereas the Mycenaeans had a more diversified range of crops. which have left a poor pollen record. At any rate, the flourishing olives are evidence against a climatic deterioration, and Dr Wright is forced to the conclusion that there is no reliable scientific evidence to support the theory that climatic change brought about the downfall of the Mycenaean civilization.

\section{Porton Revealed}

THE recent furore in Parliament and the press over the secrecy of the biological warfare work carried out at the Microbiological Research Establishment at Porton has led to a concession, albeit a slight one, from the Government; beginning in late 1968 or early 1969. Porton will hold an open day for the first time. The Ministry of Defence announced this in the House of Commons on June 12. Mr John Morris, Minister of Defence for Equipment, made the announcement and added that "the scientists at Porton have been subjected to quite intemperate attacks recently. . . . I. hope the open days... will relieve any public anxiety which may exist".

In answer to questions about the animals used at Porton, Mr Morris stated that all animals were well taken care of, but he believed that they could not be shown on television because of an 1876 Act of Parliament restricting photographs of animals. 'The' animals used in experiments certainly seem to be those normally found in biological laboratories-26,882 mice, 720 guinea-pigs, 825 hamsters, 60 voles, 63 monkeys and 44 sheep last year-and since 80 per cent of the work of the laboratory is unclassified, it would seem unlikely that the RSPCA would have cause for com- 
plaint over the treatment of the remaining 20 per cent.

This classified research did cause some debate in the House of Lords last week, however. Lord Brockway questioned the Minister of State for Foreign Affairs, Lord Chalfont, on information supplied by Porton to the United States which would be of use in the development of nerve gases such as those used in Victnam. Lord Chalfont refused to be drawn on this issue and simply stated that all information in this field exchanged with the United States was confidential. He did add that the Government was anxious that the production of biological and chemical weapons be brought into the arms control field and to this end the Government had placed the matter on the agenda at the Geneva Disarmament Conference.

\section{Defence Research}

Sir Soluy Zuckerman, the British Government's chief adviser on science, is not a man given to overstatement. Indeed, since he became chairman of the Central Advisory Council for Science and Technology, he has not been given to statements of any sort. Thus when he told the Select Committee on Science and Technology that some of the Government research establishments "are so dreary as to be unbelievable" it was bound to take notice. Sir Solly, who appeared before the committee on June 13, named no names, but the committee doubtless has its own ideas. Sir Solly firmly rejected the notion that when a defence laboratory has completed its primary purpose, it should be re-deployed in the civil research field. If the objective of a laboratory no longer applied, he said, it should be closed down. "Institutions should not be kept alive merely for the purpose of keeping them alive."

Sir Solly was also critical of some aspects of British defence contracting. He agreed with Mr David Price that there tended to be too great an element of research and development in defence contracts, and claimed that one should never build an aircraft except around existing engines. (This is an argument which the aircraft manufacturers would never accept.) He accepted the argument that "holding contracts", designed to delay expenditure, were likely to do nothing but increase it. Sir Solly also gave the committee some idea of what his advisory council has been up to since its formation. It was engaged, he said, in trying to find out what, was spent on research, both defence and civil, and where it was spent. Sir Harry Legge-Bourke was surprised that the facts were not already available, but Sir Solly said that the figures for industry's own expenditure were not known, and the breakdown in government establishments between manpower and materials was also something of a mystery. When the figures were at hand, Sir Solly said, it would be possible to make decisions, but he thought it was unlikely that his council would ever be able to determine the overall allocation of expenditure on research. Under the British accounting system, this was a minister's responsibility, and he could spend as much as he liked, within his budget, on research. Sir Solly did express a hope that it would soon be possible for his council to put forward some advice on the budget of the Science Research Council.

On the planning of defence research contracts, Sir Solly put forward the theory of the "band of uncertainty". As a project advanced, he suggested, this band should become narrower. This had not happened in a number of defence contracts, and Sir Solly said that this might be one reason why costs tended to increase. On the mobility of scientific manpower. Sir Solly observed that scientists were "sessile" rather than "mobile"-it was difficult to move them from place to place, particularly if the move would mean a change of environment for research. Finally, there was a pat on the back for the Ministry of Technologi: "The Ministry of Technology is a good thing", he declared. But it might perhaps do more for small companies, which had "a major part to play".

\section{Parliament in Britain by our Parliamentary Correspondent \\ Oceanography}

Mr Gerry Fowlen, for the Ministry of 'Technology. stated that no work in the ministry sefence research establishments is directed specifically to the development of oceanography and marine science, but that some work undertaken primarily for defence has been found to have other uses. An example of this is the application of thermal mapping techniques to such marine problems as the discharge of industrial effluents into the sea and work on underwater photography. The ministry is obtaining industry s views on worth. while research and development projects through the Construction Industry Research and Information Association. (Written answer, June 11.)

\section{Advanced Combat Aircraft}

Mr JoHN MoRris, for the Secretary of sitate for Defence, said that discussions were under way with other European governments about the possible joint development and production of an advanced combat aircraft for the late ' $70 \mathrm{~s}$, but that these discussionswith the German, Dutch, Bolgian, Italian and Canadian ministries of defence-had not yet reached any conclusions. He agreed with the points raised by several members concerning the unique amount of development work already carried out by Britain and the capabilities of the British aircraft industry, but added that the Government was not yet in a position to decide whether or not these advantages warranted Britain developing such an aircraft on her own for sale abroad, instead of working in collaboration with other countries. (Oral answer, Jume 12.)

\section{Mental Illness}

Mr Kenneth Robinson, Minister of Health, was forced to admit that the total expenditure on research into mental discase in his department in 1968-69 amounts to only $£ 54,000$. Last year the expenditur. was even less- $\$ 33,000 . \mathrm{Mr}$ Dodds-Parker pointed out that half the hospital beds in Britain were oceupied by those with mental disease. Could something not be done to increase the effort? Mr Robinson said that the main agency for medical research was the Medical Research Council, and that the Secretary of State for Education and Science would doubtless take note of the question. Lord Balniell added that 8 per cent of the MRC expenditure went on research into mental discase. Did the minister not think that there ought to be a marked improvement, or a full explanation given to the public, so that this situation be made acceptable to them ? Mr Robinson could only suggest that Lord Balniell should ask the minister responsible. for the MRC. (Oral answer, June 11.) 